\title{
Menumbuhkan Motivasi Belajar Dari Aspek Value, Expectancy dan Self Regulated Learning
}

\author{
Lilik Tahmidatien ${ }^{1}$, Wawan Krismanto ${ }^{2}$ \\ ${ }^{1}$ Departemen Sosiologi, PPPPTK PKN \& IPS Kementerian Pendidikan \& Kebudayaan \\ ${ }^{2}$ Program Studi PGSD Fakultas Ilmu Pendidikan Universitas Negeri Makassar \\ lilik.tahmidatien@kemdikbud.go.id \\ wawan.krismanto@unm.ac.id
}

\begin{abstract}
ABSTRAK
Kajian ini bertujuan untuk mengulas tentang: 1) bagaimanakah aspek Value, Expectancy dan Self Regulation pada konsep motivasi?, 2) bagaimana strategi menumbuhkan Value dan Expectancy positif serta kemampuan Self Regulated Learning pada siswa?. Metode yang digunakan adalah studi pustaka dari berbagai buku dan jurnal ilmiah. Membahas tentang motivasi, maka ada dua konsep yang penting yaitu value dan ekspektasi, yang kemudian oleh Eccles dan Wigfild diistilahkan dengan Expectancy-Value Model. Value yaitu nilai subyektif terhadap tujuan yang ingin dicapai, dengan kata lain value mengacu pada sejauh mana seseorang peduli atau menghargai tugas yang ada. Dengan demikian seberapa keras siswa belajar akan dipengaruhi oleh value yang mereka miliki atas tujuan yang telah mereka tetapkan. Agar termotivasi dalam mengejar tujuan belajar, siswa juga harus memegang harapan terhadap hasil belajar yang positif (Expectancy), yaitu harapan untuk keberhasilan mencapai tujuan. Ekspektasi atau harapan dapat memberikan pengaruh yang kuat pada motivasi siswa. Seberapa keras siswa belajar sangat bergantung pada seberapa besar harapan yang ingin mereka capai. Harapan terhadap hasil juga mencerminkan keyakinan bahwa tindakan spesifik yang dilakukannya akan membawa hasil yang diinginkan. Harapan positif akan terhubung/terkait dengan perilaku siswa dan berujung pada hasil positif yang diinginkan. Lingkungan belajar yang dekat dengan penggunaan teknologi (digital) juga menuntut keterlibatan diri karena minimnya bimbingan dan dukungan terstruktur dan intensif sepanjang proses pembelajaran berlangsung. Untuk mendorong pembelajaran yang efektif pada lingkungan seperti itu, siswa harus dilatih dalam menguasai strategi self regulation. Secara umum, self regulation dapat menjelaskan proses pembelajaran siswa dan keberhasilan mereka di kelas. Ketika siswa termotivasi untuk belajar, mereka cenderung lebih menginvestasikan waktu dan energi yang diperlukan untuk belajar dan menerapkan keterampilan self regulation yang sesuai. Maka menjadi tantangan bagi para pendidik saat ini untuk menumbuhkan value dan Expectancy yang positif pada siswa serta meningkatkan kemampuan self regulated learning mereka agar termotivasi mencapai tujuan belajar yang dinginkan.
\end{abstract}

\section{Kata kunci: Expectancy-Value Model; self regulated learning; menumbuhkan motivasi}

\section{PENDAHULUAN}

Generasi digital native sangat dekat dengan lingkungan belajar berteknologi yang memungkinkan mereka bisa belajar kapanpun, dimanapun dengan berbagai media dan sumber belajar. Hal ini difasilitasi oleh berbagai piranti teknologi yang dimanfaatkan untuk belajar. Kondisi tersebut memberikan kesempatan bagi generasi digital native untuk belajar lebih cepat, lebih luas dan mendalam. Namun demikian mereka juga dihadapkan pada tantangan penguasaan strategi belajar yang berbeda dengan generasi sebelumnya, sebab kontrol belajar berangsur-angsur berpindah dari kontrol pendidik kepada diri mereka sendiri. Hal ini menyebabkan pula proses belajar yang mereka ikuti sangat menuntut keterlibatan diri yang tinggi. Selain itu, kompleksitas konten, sistem dan perlengkapan belajar yang juga semakin tinggi menjadi tantangan tersendiri bagi generasi digital native ketika menjalani proses belajar yang diikuti. Tak jarang mereka menjadi mudah putus atau frustasi dan akhirnya gagal mengikuti proses pembelajaran sampai akhir, pembelajaran melalui e-learning misalnya. Untuk itu motivasi dalam mengikuti serangkaian proses pembelajaran menjadi sangat penting bagi generasi digital native dan menjadi tantangan berat pula bagi para pendidik. Para pendidik tidak hanya berpikir keras untuk menarik dan memotivasi peserta 
didik untuk mengikuti rangkaian proses belajarnya, namun juga harus menjaga konsistensi motivasi peserta didiknya sehingga dapat berhasil sampai akhir bahkan sampai pada pasca pembelajarannya.

Schunk menegaskan bahwa motivasi sangat terkait dengan pembelajaran, sebab motivasi dan pembelajaran bisa saling mempengaruhi (Schunk, 2012). Motivasi siswa bisa mempengaruhi apa dan bagaimana mereka belajar. Sebaliknya, saat siswa belajar dan mendapatkan keyakinan dan pengalaman bahwa selama belajar mendapat dan merasakan perubahan pada dirinya, maka mereka termotivasi untuk terus mengikuti proses pembelajaran selanjutnya. Slavin menegaskan bahwa siswa yang secara akademis tidak termotivasi untuk belajar, maka ia tidak akan belajar (Slavin, 2018).

Pada konteks proses pembelajaran generasi digital native yang identitik dengan pemanfaatan teknologi tinggi, motivasi tetap menjadi sebuah perhatian yang besar. Hal ini karena motivasi akan mempengaruhi arah, intensitas, kegigihan, dan kualitas perilaku belajar di mana siswa ikut terlibat didalamnya. Motivasi siswa akan menghasilkan, mengarahkan, dan mendukung apa yang mereka lakukan untuk belajar (Ambrose, Bridges, DiPietro, Lovett, \& Norman, 2010). Pada situasi yang dialami siswa generasi digital native, dimana keharusan keterlibatan belajar justru semakin lekat dengan proses belajarnya, maka motivasi belajar generasi digital native menjadi semakin memerlukan perhatian. Apalagi jika dikaitkan dengan pembelajaran dengan teknologi seperti pembelajaran daring (e-learning), pembelajaran terbuka dan pembelajaran jarak jauh, dimana motivasi belajar menjadi kunci utama keberhasilannya. Studi yang dilakukan Bhuasiri menunjukkan bahwa menciptakan kesadaran teknologi, motivasi dan mengubah perilaku pelajar sangat dibutuhkan untuk keberhasilan implementasi e-learning (Bhuasiri, Xaymoungkhoun, Zo, Rho, \& Ciganek, 2012). Bahkan Keller dan Suzuki menegaskan, meskipun ada kesamaan dalam masalah motivasi dalam semua kondisi pembelajaran, ada tantangan motivasi yang spesifik dalam sistem pembelajaran e-learning, misalnya, angka drop-out cenderung lebih tinggi daripada di tatap muka, peserta didik sering merasa terisolasi dan tingkat interaktivitas pembelajaran rendah dan tidak memliki keragaman studi kasus dan proyek seperti yang ada pada pembelajaran tatap muka (Keller \& Suzuki, 2004).

Selain itu, tidak seperti pengaturan pembelajaran tradisional, lingkungan belajar yang dekat dengan penggunaan teknologi (digital) juga menuntut keterlibatan diri karena minimnya bimbingan dan dukungan terstruktur dan intensif sepanjang proses pembelajaran berlangsung. Untuk mendorong pembelajaran yang efektif di lingkungan seperti itu, siswa harus dilatih dalam menguasai strategi self regulated (Winters, Greene, \& Costich, 2008). Hal ini selaras dengan model hubungan motivasi dengan pembelajaran Schunk, bahwa salah satu variabel yang berpengaruh selama siswa menyelesaikan proses belajar adalah pengaturan diri (self regulation) (Schunk, 2012). Secara umum, self regulation dan motivasi secara bersama-sama dapat menjelaskan proses pembelajaran siswa dan keberhasilan mereka di kelas. Ketika siswa termotivasi untuk belajar, mereka cenderung lebih menginvestasikan waktu dan energi yang diperlukan untuk belajar dan menerapkan keterampilan self regulation yang sesuai. Ketika siswa dapat berhasil menerapkan strategi self regulation dalam belajarnya, mereka cenderung lebih termotivasi untuk menyelesaikan tugas dan proses pembelajarannya (Zimmerman, 2015).

Self regulation merupakan salah satu aspek metakognisi, yang meliputi (1) pengetahuan atau kesadaran orang tentang proses kognitif mereka, dan (2) kemampuan untuk menggunakan mekanisme pengaturan diri untuk mengontrol proses belajar. Kemampuan menggunakan mekanisme pengaturan diri untuk mengontrol proses belajar itulah yang disebut dengan selfregulated learning. Dengan demikian selfregulated learning adalah mekanisme pengaturan kognisi yang digunakan secara aktif oleh siswa selama memecahkan berbagai tugas dan permasalahan selama proses belajar (Zimmerman, 2015). Siswa dengan strategi self regulated learning yang efektif kecenderungannya lebih siap untuk menghadapi tantangan dunia yang cepat berubah seperti halnya yang dihadapi oleh generasi digital native (Cheng \& Chau, 2013).

Oleh karena itu menjadi menarik untuk dikaji tentang bagaimana motivasi belajar para generasi digital native. Konsep motivasi belajar begitu luas dan meliputi berbagai aspek yang kompleks didalamnya, untuk itu makalah ini membatasi pada 2 aspek saja yaitu value, expectancy dan self regulated learning dengan 
rumusan masalah: 1) bagaimanakah aspek Value dan Expectancy dan Self Regulation pada konsep motivasi?, 2) bagaimana strategi menumbuhkan Value dan Expectancy positif serta kemampuan Self Regulated Learning pada siswa?.

\section{KAJIAN PUSTAKA \& PEMBAHASAN}

Motivasi adalah alasan mengapa orang bersikap dan berperilaku dengan cara yang mereka lakukan. Santrock menjelaskan bahwa motivasi merupakan proses yang memberi semangat, arah, dan kegigihan perilaku, artinya, perilaku yang termotivasi adalah perilaku yang penuh energi, terarah dan bertahan lama (Santrock, 2018). Motivasi juga mengarahkan seorang individu pada tujuan-tujuan tertentu (Eccles \& Wigfield, 2002).

Telah dijelaskan pada bagian awal bahwa motivasi memiliki keterkaitan erat dengan keberhasilan pembelajaran. Dalam bukunya Learning Theories, Schunk menggambarkan sebuah model yang menjelaskan hubungan motivasi dan pembelajaran sebagai berikut (Schunk, 2012).

\begin{tabular}{|c|c|c|}
\hline Pra-Tugas & Selama Tugas & Pasca Tugas \\
\hline Tujuan & $\begin{array}{c}\text { Variabel Pengajaran } \\
\text { - Guru }\end{array}$ & Atribut \\
\hline $\begin{array}{l}\text { Ekspektasi } \\
\text { - Keberhasilan diri } \\
\text { - Hasil }\end{array}$ & $\begin{array}{l}\text { - Umpan Balik } \\
\text { - Materi } \\
\text { - Peralatan }\end{array}$ & $\begin{array}{l}\text { Tujuan } \\
\text { Ekspektasi }\end{array}$ \\
\hline Pengaruh & $\begin{array}{c}\text { Variabel Kontekstual } \\
\bullet \quad \text { Teman }\end{array}$ & Pengaruh \\
\hline Nilai & - Lingkungan & Nilai \\
\hline Kebutuhan & Variabel Personal & Kebutuhan \\
\hline Dukungan Sosial & $\begin{array}{l}\text { - Susunan pengetahuan } \\
\text { - Penguasaan keterampilan } \\
\text { - Pengaturan diri } \\
\text { - Usahan aktivitas } \\
\text { - Keuletan }\end{array}$ & Dukungan Sosial \\
\hline
\end{tabular}

Tugas yang dimaksud dalam model tersebut merupakan aktivitas yang harus dilakukan siswa. Pada pra-tugas, beragam tujuan dimiliki oleh siswa baik tujuan yang sifatnya akademik seperti pencapaian kompetensi, kecepatan menguasai materi, ataupun non akademik seperti berkelompok, berkolaborasi, bersosialisasi dan sebagainya. Selain itu siswa juga memiliki harapan (expectation) dalam mengerjakan tugas, pemahaman tentang pentingnya pembelajaran atau penyelesaian tugas (value), kebutuhan dan dukungan dari lingkungan di sekelilingnya bisa berupa bimbingan guru, orang tua, teman dan sebagainya. Selanjutnya, tiga variabel motivasi berperan selama pembelajaran:1) Variabel pengajaran seperti guru, materi dan peralatan yang selain dipandang sebagai faktor berpengaruh pada jalannya proses pembelajaran, variabel ini juga dipandang mempengaruhi motivasi. 2) Variabel kontekstual yang mencakup sumber sosial dan lingkungan dapat mendorong pada kondisi lemah atau kuatnya motivasi, misal teman, keluarga, iklim belajar sekolah dll. 3) Variabel personal yang mencakup susunan pengetahuan (materi), penguasaan keterampilan dan pengaturan diri yang akan berpengaruh pada stabilitas motivasi selama proses pembelajaran. Pada pasca tugas, keberlanjutan proses belajar yang dialami siswa setelah menyelesaikan tugasnya akan dipengaruhi oleh atribut, tujuan, harapan, nilai, kebutuhan dan dukungan sosial yang didapatkan atau dicapai setelah menyelesaikan serangkaian tugas yang diberikan kepadanya. Semakin positif yang didapat atau dicapai maka motivasi akan semakin baik pula.

\section{Aspek Expectancy dan Value Dalam Motivasi}

Membahas tentang motivasi maka ada dua konsep penting yang penting dalam memahaminya yaitu value dan ekspektasi, yang kemudian oleh Eccles dan Wigfild diistilahkan dengan Expectancy-Value Model yang dikembangkan dan sejak 1983 (Wigfield \& Eccles, 2000), atau dijelaskan oleh Slavin 
sebagai Expectancy Theory atau Expectancy Model atau Expectancy-Valence Model (Slavin, 2018).

\section{a. Value}

yaitu nilai subyektif terhadap tujuan yang ingin dicapai, atau dengan kata lain value mengacu pada sejauh mana seseorang peduli atau menghargai tugas yang ada. Santrock mengindikasikan bahwa seberapa keras siswa belajar juga dipengaruhi oleh value yang mereka miliki atas tujuan yang telah mereka tetapkan, ia mendefinisikan value sebagai keyakinan, sikap, cara berpikir seseorang tentang apa yang seharusnya dilakukan atas tujuan yang telah ditetapkan (Santrock, 2018).

Menurut Eccles et all., Nilai subyektif terdiri dari empat nilai yang saling terkait: nilai intrinsik, nilai utilitas, nilai pencapaian, dan nilai biaya. Nilai intrinsik mengacu pada kesenangan atau kepuasan yang dialami saat terlibat dalam tugas. Nilai utilitas mengacu pada seberapa berguna tugas tersebut untuk mencapai tujuan saat ini dan masa depan. Nilai pencapaian mengacu pada sejauh mana tugas dianggap penting untuk identitas individu. Biaya mengacu pada apa yang didapat dan apa yang dikeluarkan sebagai konsekuensi terlibat dalam tugas (Eccles \& Wigfield, 2002) (Wigfield \& Eccles, 2000).

Eccles dan Cambria mendefinisikan value yang dikaitkan dengan kualitas tugas yang berbeda dan bagaimana kualitas tersebut mempengaruhi keinginan individu untuk menyelesaikan tugas tersebut. Lebih lanjut, value bersifat subyektif karena setiap individu bisa saja memberikan value yang berbeda untuk sebuah tugas yang sama (Wigfield \& Cambria, 2010). Hal ini bisa diilustrasikan pada keberhasilan atau prestasi belajar matematika di sebuah kelas. keberhasilan mencapai prestasi matematika sangat berharga dan menjadi sebuah kebanggan tersendiri bagi beberapa siswa, tapi belum tentu bagi sebagian siswa lainnya.

\section{b. Expectancy}

Expectancy merupakan harapan untuk keberhasilan mencapai tujuan. Eccles \& Wigfield mendefinisikan ekspektasi sebagai keyakinan tentang seberapa baik mereka akan melakukan tugas yang akan datang, baik yang sifatnya segera atau jangka panjang (Eccles \& Wigfield, 2002). Kemudian Santrock menegaskan bahwa harapan dapat memberikan pengaruh yang kuat pada motivasi siswa. Seberapa keras siswa akan belajar sangat bergantung pada seberapa besar harapan yang akan mereka capai. Jika mereka berharap untuk berhasil, mereka lebih cenderung bekerja keras untuk mencapai tujuan, daripada jika mereka berharap (memprediksi/berkeyakinan) untuk gagal (Santrock, 2018). Agar termotivasi dalam mengejar tujuan tertentu, siswa harus memegang harapan hasil yang positif. Harapan terhadap hasil mencerminkan keyakinan bahwa tindakan spesifik yang dilakukan akan membawa hasil yang diinginkan. Harapan positif akan terhubung/terkait dengan perilaku siswa dan berujung pada hasil positif yang diinginkan. Sebaliknya, ekspektasi negatif memberi keyakinan bahwa tindakan spesifik tidak memengaruhi hasil yang diinginkan. Sebagai contoh, seorang siswa mungkin berpikir, "seperti apapun kerasnya saya belajar, saya tetap tidak akan mendapatkan nilai bagus"

Ambrose et. All. menggambarkan pengaruh expectancy dan value pada pencapaian pembelajaran seperti pada gambar berikut ini.

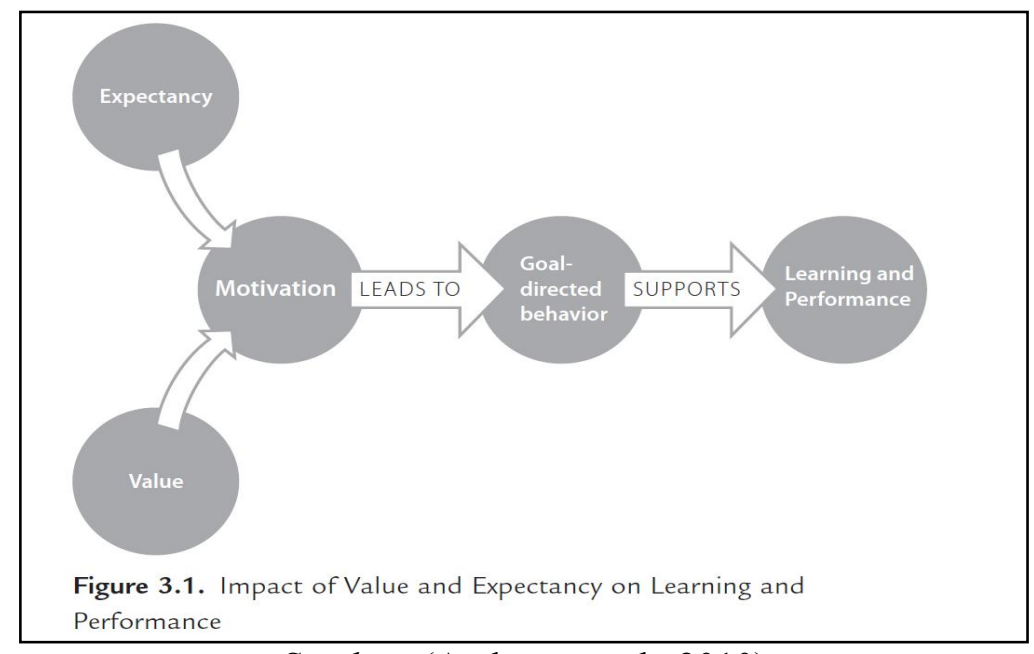

Sumber: (Ambrose et al., 2010) 
Jadi expectancy dan value berinteraksi untuk mempengaruhi tingkat motivasi dan keterlibatan dalam perilaku-perilaku yang diarahkan pada pencapaian tujuan pembelajaran. Kepedulian yang positif terhadap proses belajar, kepuasan saat mengikuti proses belajar, kebermanfaatan serta harapan yang positif akan mengarahkan individu yang belajar berperilaku yang positif pula sehingga akan mempengaruhi pada pencapaian tujuan belajar yang optimal, dan begitupula sebaliknya. Kemudian, ketika individu menganggap diri mereka mampu dan berharap untuk berhasil dalam belajar, mereka lebih cenderung berinsisiatif dan memilih untuk terlibat aktif di dalamnya, lalu konsisten bertahan mengikuti serangkaian kegiatan belajar dan akhirnya mencapai hasil yang diinginkan.

Berdasarkan uraian konsep tentang Value dan expectancy di atas, maka menjadi sesuatu yang perlu dipikirkan baik oleh pendidik, perancang/desainer instruksional maupun pengelola lembaga pendidikan untuk menumbuhkan atau mengembangkan value dan ekpektasi yang positif pada peserta didik, termasuk peserta didik generasi digital native yang dekat sekali kesehariannya dengan teknologi. Hal ini perlu direkomendasikan seiring dengan beberapa studi terdahulu tentang value dan ekspektasi yang telah dipublikasikan, diantaranya:

a. Studi Dietrich et.all. (2017) mengkaji tentang ekspektasi dan value pada mahasiswa keguruan di Jerman. Mereka mengkaji tentang: 1) sejauh mana variasi Ekspektasi (Ekspektasi untuk keberhasilan dan kepercayaan kompetensi), Value task (intrinsik, pencapaian, dan nilai utilitas, dan nilai biaya) dan upaya pada tingkat situasi pembelajaran, tingkat topik, dan tingkat studi dan 2) sejauh mana hubungan/keterkaitan ekspektasi dan value task dengan usaha mahasasiswa dalam mencapai tujuan?. Hasilnya menunjukkan terdapat variasi yang beragam pada semua tingkatan. Mereka menemukan adanya hubungan yang positif antara value task dengan usaha mahasiswa mencapai tujuan yang diharapkan dan adanya hubungan positif pula antara ekspektasi dengan usaha mahasiswa ditinjau dari situasi pembelajaran dan tingkat topik. (Dietrich, Viljaranta, Moeller, \& Kracke, 2017)

b. Studi Jianzhong Xu (2017) yang mengkaji tentang ekspektasi dan value pada tugas pekerjaan rumah (home work) pada 1799 siswa kelas 10 dan 11 di China. Hasil studi mengungkapkan bahwa, dibandingkan dengan laki-laki, perempuan memiliki skor value task yang jauh lebih tinggi. Sementara itu, tidak ada perbedaan rata-rata yang signifikan secara statistik di seluruh tingkat kelas. Temuannya lainnya ekspektansi dan value task berkorelasi positif dengan usaha para siswa terkait tugas pekerjaan rumah mereka, pengaturan emosi, dan penyelesaian tugas rumah mereka. (Xu, 2017)

c. Studi Bergey et.all (2018) yang salah satu fokusnya adalah mengkaji tentang hubungan efikasi diri akademik dan value task dengan kinerja akademik, kepuasan akademik, dan retensi institusi pada 482 mahasiswa baru yang dikelompokkan menjadi mahasiswa yang mengalami kesulitan membaca dan yang tidak. Hal yang baru pada penelitian ini adalah menguji korelasi kepuasan akademik dari kerangka expectancy-value. Salah satu hasil studi tersebut adalah baik academic Self Efficacy maupun Subjective Value Task (terutama intrinsic value paling signifikan) berkorelasi positif baik pada academic performance maupun academic satisfaction. Temuan tersebut terjadi baik pada kelompok mahasiswa baru dengan kesulitan membaca maupun yang tidak. (Bergey, Parrila, \& Deacon, 2018).

\section{Self Regulation}

Salah satu variabel penting juga dalam motivasi adalah pengaturan diri (self regulation). Dalam konteks pembelajaran diistilah dengan self regulated learning. Konsep self regulated learning berawal sejak tahun 1980an sebagai sebuah research problem dan pada dekade ini berkembang menjadi konsep penting bagi para peneliti dan guru. Salah satu alasan yang mengarahkan para peneliti fokus mengkaji tentang self regulated learning terletak pada kenyataan bahwa hidup di masyarakat saat ini pembelajaran seumur hidup menjadi semakin penting dan lingkungan belajar informal terus berkembang, sehingga membutuhkan keterampilan self regulated (Beishuizen \& Steffens, 2011). Selfregulated learning merupakan salah satu aspek metakognisi, yang meliputi (1) pengetahuan atau kesadaran orang tentang proses kognitif mereka, dan (2) kemampuan untuk menggunakan mekanisme pengaturan diri untuk mengontrol proses belajar. Kemampuan yang kedua itulah yang disebut dengan self- 
regulated learning. Dengan demikian selfregulated learning adalah mekanisme pengaturan kognisi yang digunakan secara aktif oleh siswa selama memecahkan berbagai permasalahan (Zimmerman, 2015).

Ketertarikan pada self regulated siswa sebagai topik formal penelitian muncul antara tahun 1970-an sampai awal 1980-an sebagai usaha untuk mempelajari pengendalian diri manusia. Kajian self regulated learning muncul berdasarkan berbagai sumber teoritis selama tahun 1970-an dan 1980-an, sebagai contoh adalah penelitian operan yang mengadaptasi prinsip dan teknologi dari Skinner untuk penggunaan pribadi, terutama penggunaan pengendalian lingkungan, perekaman diri, dan penguatan diri. Antara tahun 1970-an dan 1980-an pula, muncul tulisan-tulisan penekanan Vygotsky yang diterbitkan dalam bahasa Inggris, yang isinya menjelaskan secara lebih lengkap bagaimana percakapan batin anak-anak muncul dari interaksi sosial dan berfungsi sebagai sumber pengendalian diri (Zimmerman, 2015).

Konsep Self regulated learning melibatkan proses metakognitif, motivasi, dan perilaku pribadi untuk memperoleh pengetahuan dan keterampilan, seperti penetapan tujuan, perencanaan, strategi belajar, penguatan diri, refleksi diri, dan belajar sendiri. Perspektif self regulated learning mengubah fokus analisis pendidikan dari kemampuan belajar siswa dan lingkungan belajar sebagai entitas yang tetap, kepada proses yang dimulai sendiri oleh siswa dengan menentukan metode dan lingkungan yang sesuai untuk pembelajaran mereka. Pendekatan ini memandang pembelajaran sebagai kegiatan yang dilakukan siswa untuk dirinya sendiri secara proaktif, daripada sebagai peristiwa rahasia yang terjadi pada mereka secara reaktif sebagai hasil dari pengalaman belajar (Zimmerman, 2015). Dengan demikian selfregulated learning dipersepsikan sebagai perasaan, pikiran, dan tindakan yang dihasilkan oleh siswa, yang secara sistematis diarahkan untuk mencapai tujuan mereka. Konsep yang dikemukakan Zimmerman tersebut melihat bahwa pengaturan diri merupakan interaksi antara kepribadian seseorang, perilakunya (yaitu, motivasi, kognitif dan komponen afektif) dan lingkungan eksternal. Hal ini merujuk pada teori Albert Bandura yaitu teori kognitif sosial dimana manusia dipandang sebagai hasil struktur kausal yang interdependen antara pribadi, perilaku dan lingkungannya. Tidak seperti behaviorisme, yang menekankan pengaruh lingkungan pada perilaku manusia, teori kognitif sosial melihat penyebab perilaku manusia dalam apa yang disebut determinisme timbal balik. Ini berarti bahwa layout perilaku biologis dan internal dari individu serta lingkungan eksternal saling berinteraksi. Dengan kata lain, self regulated dipandang sebagai interaksi proses triadik yaitu pribadi, perilaku dan lingkungan (Zimmerman, 2015).

Model umum self regulated learning berkonsentrasi pada pengaturan kognisi, perilaku motivasi dan konteks. Self regulated learning dipersepsikan sebagai sebuah proses yang aktif dan konstruktif di mana para siswa menetapkan tujuan untuk pembelajaran mereka dan kemudian berusaha untuk memantau, mengatur, dan mengendalikan kognisi, motivasi, dan perilaku mereka, dipandu dan dibatasi oleh tujuan dan makna kontekstual di lingkungannya (Pintrich, 2000). Sebelumnya Pintrich memformulasikan kerangka kerja konseptual untuk mempelajari self regulated learning yang terdiri dari empat fase: perencanaan, penetapan tujuan, pengendalian dan refleksi. Dalam model ini, self regulated dipahami sebagai kemampuan siswa dari aspek kognitif, motivasi dan metakognitif aktif dalam proses pembelajaran untuk mencapai tujuan yang ditetapkan (Pintrich, 1999).

Para peneliti yang mengkaji self regulated learning menjelaskan bahwa siswa yang terlatih mandiri memiliki kemampuan untuk menetapkan tujuan, menunjukkan tujuan pembelajaran penguasaan dan kepercayaan diri yang tinggi dalam pembelajaran mereka, dan menghubungkan ketidakpuasan hasil yang dicapai dengan ketidaksesuaian strategi belajar atau kegagalan mereka untuk mengelola sumber belajar secara efektif (Pintrich, 2004; Zimmerman, 2008). Sebaliknya, siswa dengan penguasaan diri yang kurang terampil, sering gagal untuk menetapkan tujuan dan cenderung mengejar tujuan yang menghindarkan mereka dari tugas, menunjukkan kepercayaan diri yang rendah dalam belajar serta atribut kinerja mereka yang tidak memuaskan terutama yang bersumber dari eksternal, seperti instruktur atau desain pembelajaran yang tidak efektif.

Self regulated learning di era pembelajaran abad 21 tidak hanya fokus pada kajian self regulated learning pembelajaran tradisional, namun juga telah berkembang pada kajian tentang self regulated learning pada proses pembelajaran yang memanfaatkan dan mengintergrasikan teknologi. Teknologi digital yang berkembang saat ini membuka pintu 
gerbang bagi alternatif-alternatif strategi pembelajaran yang baru yang mendukung penguasaan keterampilan self regulated learning (Foster, Rawson, \& Dunlosky, 2018). Kemajuan dalam teknologi pembelajaran juga memberi kesempatan yang luas bagi siapa saja yang sedang dan akan melakukan pembelajaran untuk melakukan eksplorasi learning resouces yang luas dan besar (big data learning), memfasilitasi kegiatan mengajar dan meningkatkan kuantitas dan kualitas pembelajaran. Teknologi telah menjadi sarana yang efisien untuk memungkinkan akses yang luas pada konten yang besar dan beragam (Maldonado-Mahauad, Pérez-Sanagustín, Kizilcec, Morales, \& Munoz-Gama, 2018). Ketika teknologi menjadi semakin dekat dan familiar bagi setiap individu maka pada saat yang sama pula konsep self regulated learning menjadi sangat penting dalam pembelajaran berbasis teknologi (Narciss, Proske, \& Koerndle, 2007). Hal tersebut tentu berkaitan dengan bagaimana teknologi yang digunakan mampu memaksimalkan keberhasilan belajar mereka. Pada konteks ini Self regulated learning dalam hal manajemen waktu, metakognisi, pemikiran kritis, dan usaha mengelola belajar memiliki korelasi positif yang signifikan dengan keberhasilan akademis dalam pembelajaran online (Broadbent \& Poon, 2015).

Sejalan dengan berkembangnya teknologi informasi dan komunikasi dalam konteks pendidikan, teori yang mendasari self regulated learning telah mengalami pergeseran pula pada perhatiannya tentang pentingnya teknologi untuk pembelajaran. Hal ini kemudian mendorong para peneliti terdahulu memperkenalkan model konseptual untuk self regulated learning dalam konteks online dengan mengelaborasi komponen-komponen seperti penggunaan sumber daya, penggunaan strategi, motivasi, perencanaan dan pemantauan (Kizil \& Savran, 2016).

Beberapa penelitian terdahulu tentang pemanfaatan teknologi dalam pembelajaran yang secara spesifik dikaitkan dengan strategi self regulated learning pada siswa, antara lain:

a. Hsiao dkk. menyelidiki korelasi antara tingkat self-regulated siswa dengan hasil belajar yang difasilitasi WebQuest learning berbasis self-regulated learning. Sebanyak 193 pelajar bahasa kelas enam berpartisipasi dalam penelitian ini, dan data terdiri dari skor pretest dan postest dari para peserta. Studi ini menyimpulkan bahwa mengintegrasikan fungsi-fungsi self regulated learning ke dalam instruksi bahasa berbasis WebQuest dapat meningkatkan perilaku self regulated learning dalam pembelajaran bahasa (Hsiao, Tsai, Lin, \& Lin, 2012).

b. Aysel Sahin Kizil \& Zehra Savran mengadopsi self regulated learning sebagai kerangka teoritis untuk mengkaji penggunaan teknologi oleh siswa untuk tujuan pembelajaran bahasa. Penelitian ini menunjukkan profil pemanfaatan teknologi yang digunakan sebagian besar peserta pembelajaran antara lain: ada korelasi positif yang signifikan antara self regulated learning yang difasilitasi oleh TIK dengan kinerja akademik siswa, terdapat sikap positif siswa terhadap peran alat TIK dalam memfasilitasi pencapaian tujuan pembelajaran bahasa mereka, terdapat sikap positif terhadap penggunaan alat TIK sebagai sumber daya dalam pembelajaran bahasa (Kizil \& Savran, 2016)

c. Garry Chang dan Juliana Chau mengeksplorasi hubungan antara kemampuan self-regulated learning) siswa dan pencapaian ePortfolio mereka dalam program peningkatan bahasa. Responden diminta membuat beberapa pameran ePortfolio untuk menunjukkan pengalaman belajar bahasa Inggris mereka selama tiga bulan kemudian di minta mengisi instrumen yang menunjukkan strategi self regulated learning yang mereka gunakan selama pembelajaran bahasa. Temuannya menunjukkan bahwa keterampilan kognitif tingkat tinggi (yaitu elaborasi, organisasi, pemikiran kritis), strategi kontrol metakognitif (yaitu pengaturan diri) dan strategi pembelajaran kolaboratif (yaitu pembelajaran sejawat) berkorelasi positif dengan pencapaian ePortfolio peserta (Cheng \& Chau, 2013).

d. Moon-Heum Choa, Yanghee Kimb, Dong Ho Choia menguji efek dari tingkat self regulated learning pada persepsi mereka tentang komunitas inquiriy (CoI) dan hasil afektif mereka (sikap terhadap tugasspesifik dan self-efficacy). Peserta adalah 180 pebelajar yang terdaftar dalam kursus online pembelajaran bahasa. Dengan menggunakan metode analisis klaster, level-level self regulated learning dikelompokkan menjadi empat level (pengaturan tinggi, pengaturan sedang ranpa upaya, pengaturan sedang tanpa nilai, dan pengaturan rendah). Hasil uji ANOVA mengungkapkan bahwa siswa yang 
memiliki self regulated learning tinggi menunjukkan persepsi terhadap CoI yang lebih kuat dan mencapai hasil afektif yang lebih tinggi, dibandingkan dengan siswa yang memiliki self regulated learning yang rendah. Temuan ini menegaskan bahwa self regulated learning dapat memainkan peran penting dalam kerangka komunitas inquiry (Cho, Kim, \& Choi, 2017).

\section{Strategi Meningkatkan Value dan} Ekspektansi Positif Dalam Pembelajaran

Menjadi sebuah keharusan bagi setiap pendidik untuk juga berpikir tentang menumbuhkan dan menjaga konsistensi motivasi yang dimiliki siswanya dalam mengikuti proses pembelajaran. Secara lebih spesifik adalah untuk generasi digital native dimana konten, sistem dan peralatan belajarnya lebih kompleks. Salah satu alternatif yang dapat dilakukan adalah melakukan strategi peningkatan value dan ekspektansi positif para siswanya. Ambrose memberikan panduan bagaimana melakukan hal tersebut (Ambrose et al., 2010), yaitu:

a. Strategi untuk Menetapkan Nilai

1) Hubungkan Materi dengan Minat Siswa. Siswa biasanya lebih termotivasi untuk terlibat dengan materi yang menarik minat mereka atau memiliki relevansi dengan aspek-aspek penting dalam kehidupan mereka.

2) Memberikan Tugas Otentik dan Nyata. Menetapkan masalah dan tugas yang memungkinkan siswa untuk melihat dengan jelas dan konkret relevansi dan nilai konsep dan teori yang abstrak.

3) Tampilkan Relevansi dengan Kehidupan Akademik Siswa. Siswa kadang-kadang tidak menghargai pengalaman belajar saat ini karena mereka tidak melihat nilai relevansinya terhadap ilmu yang digeluti mereka.

4) Tunjukkan Relevansi Keterampilan Tingkat Tinggi Untuk Masa Depan Kehidupan Profesional Siswa. Siswa sering fokus pada materi belajar dan abai pada pengembangan keterampilan dan kemampuan mereka untuk hal diluar itu (misalnya, penalaran kuantitatif, berbicara di depan umum, menulis persuasif, keterampilan bekerja secara tim) yang dibutuhkan bagi kehidupan profesional mereka kelak.

5) Tunjukkan Gairah dan Antusiasme. Antusiasme dan gairah bisa sangat kuat dan menular. Antusiasme dapat meningkatkan rasa ingin tahu siswa dan memotivasi mereka untuk mencari tahu apa yang membuat bersemangat, kemudian mengarahkan mereka untuk lebih terlibat dalam pembelajaran.

b. Strategi Yang Membantu Siswa Membangun Harapan Positif

1) Pastikan Penyelarasan Tujuan, Penilaian, dan Strategi Pembelajaran. Ketika ketiga komponen pembelajaran tersebut diselaraskan dan siswa mengetahui tujuan, diberi kesempatan untuk berlatih dan mendapatkan umpan balik, serta mampu menunjukkan tingkat pemahaman mereka, maka siswa akan bersemangat dan memiliki harapan positif. Siswa juga memiliki gambaran yang lebih koheren tentang apa yang diharapkan, dengan demikian lebih termotivasi karena mereka merasa lebih percaya diri dan mampu mengontrol pembelajaran, serta memprediksi nilai yang akan mereka capai.

2) Identifikasi Tingkat Tantangan yang Tepat. Menetapkan tujuan yang menantang tetapi dapat dicapai sangat penting untuk memotivasi siswa secara optimal. Untuk melakukannya, perlu tahu siapa siswa yang dihadapi- dalam hal pengetahuan dan pengalaman mereka sebelumnya serta rencana dan tujuan kedepan mereka. Preassessment mungkin berguna dalam mengevaluasi pengetahuan sebelumnya dan tujuan kedepan mereka.

3) Buat Tugas yang Memberikan Tantangan. Di satu sisi, jika pembelajaran cenderung memungkinkan siswa untuk mudah berhasil, mereka tidak akan termotivasi untuk terlibat dalam proses pembelajaran. Untuk itu perlu menetapkan standar yang menantang tetapi memungkinkan dapat dicapai siswa.

4) Berikan Peluang Keberhasilan Awal. Harapan untuk keberhasilan masa depan dipengaruhi oleh pengalaman masa lalu. Karenanya, kesuksesan awal dapat membangun rasa percaya diri. Strategi ini sangat penting dalam proses pembelajaran dirasakan sulit, apalagi siswa yang belajar dengan tingkat kecemasan karena berbagai alasan.

5) Artikulasikan Harapan. Artikulasikan tujuan belajar dengan jelas kepada siswa sehingga mereka tahu apa hasil yang diinginkan. Kemudian jelaskan kepada siswa apa yang diharapkan dari mereka agar mencapai tujuan tersebut. Ini akan 
membantu membuat hubungan antara tindakan dan hasil yang diinginkan lebih sinkron, konkrit dan nyata, sehingga menciptakan harapan pada pencapaian hasil yang lebih positif.

6) Berikan Rubrik. Rubrik adalah cara yang secara eksplisit mewakili ekspektasi kinerja dan dengan demikian dapat mengarahkan perilaku siswa ke arah tujuan yang dimaksudkan/diinginkan. Misal dapat nila A jika.... Dapat nilai A- jika....

7) Berikan Umpan Balik. BUmpan balik memberikan informasi tentang kemajuan menuju tujuan yang akan dicapai atau ketercapaian kompetensi. Umpan balik memiliki efek motivasi yang kuat dan umpan balik paling efektif adalah ketika dilakukan tepat waktu dan bersifat konstruktif.

8) Be Fair. Pastikan bahwa standar dan kriteria yang digunakan untuk menilai pekerjaan siswa dikelola secara adil. Memberikan standar atau rubrik yang jelas dan detail adalah salah satu contohnya.

9) Memberi gambaran pada Siswa Tentang Bagaimana Bisa Berhasil atau Gagal. Hal ini memberi siswa rasa kontrol yang lebih baik atas hasil yang akan mereka alami dan pada gilirannya memengaruhi harapan mereka untuk sukses. Selain itu mendidik mereka tentang atribusi (hal apa saja) yang membuat sukses atau gagal.

10) Jelaskan Strategi Belajar yang Efektif. Siswa mungkin tidak dapat mengidentifikasi cara-cara di mana mereka harus dengan tepat mengubah perilaku belajar mereka setelah mengalami kegagalan. Dalam hal ini, penting untuk membahas strategi belajar yang efektif untuk memberi mereka alternatif sebagai solusi atas perilaku yang mengakibatkan hasil buruk mereka.

11) Berilah Siswa Peluang Untuk Melakukan Refleksi. Penting untuk memberi siswa kesempatan untuk merefleksikan proses belajar yang mereka ikuti. Memfasilitasi refleksi kepada mereka dapat dilakukan dengan memberikan pertanyaan spesifik yang dapat mendukung motivasi mereka. Misalnya, bertanya kepada siswa "Apa yang kalian pelajari dari tugas ini?" Atau "Apa hal yang paling berharga yang kalian dapat setelah mengikuti proses belajar/mengerjakan tugas/menyelesaikan proyek ini?".

\section{c. Strategi Mendorong Self Regulation di Kelas}

Banyak literatur menunjukkan berbagai strategi pembelajaran yang efektif untuk mendorong pengaturan diri (self regulation) di kelas, antara lain: instruksi dan pemodelan langsung, praktik terbimbing dan independen, dukungan sosial, umpan balik dan praktik reflektif (Zumbrunn, Tadlock, \& Roberts, 2011). Selain itu, evaluasi diri terhadap kemajuan belajar siswa juga perlu diterapkan karena membantu siswa fokus pada proses self regulation dan dapat meningkatkan motivasi serta meningkatkan kemampuan mereka. Penelitian menunjukkan bahwa mendorong siswa untuk melakukan evaluasi diri secara berkala meningkatkan efikasi diri, motivasi untuk mengatur diri sendiri, dan penggunaan strategi belajar yang diatur sendiri (HamiltonEkeke \& Joy-Telu, 2016).

\section{KESIMPULAN \& SARAN}

Mengkaji tentang motivasi amatlah luas dan melibatkan berbagai aspek yang kompleks didalamnya. Bagi seseorang yang berkecimpung dalam dunia pendidikan menjadi wajib hukumnya memahami segala aspek yang ada pada motivasi agar dalam semua bentuk perencanaan, pelaksanaan bahkan evaluasinya memperhatikan aspekaspek yang ada pada motivasi. Dengan demikian pelaksanaan pembelajarannya akan mampu menumbuhkan motivasi belajar siswanya sejak mulai dari awal sampai akhir bahkan pasca pembelajaran. Lebih spesifik lagi adalah bagaimana memotivasi proses pembelajaran pada generasi digital native yang sangat dekat dengan lingkungan belajar berteknologi. Berbagai studi menunjukkan bahwa meskipun ada kesamaan dalam masalah motivasi dalam semua kondisi pembelajaran, ada tantangan motivasi yang spesifik dalam sistem pembelajaran yang memanfaatkan teknologi. Dengan sistem dan proses pembelajaran yang kompleks tentu membutuhkan motivasi yang baik dari siswanya agar mampu mengikuti semua proses dan aktivitasnya sejak awal sampai akhir. Tentu saja semua upaya meningkatkan motivasi belajar siswa haruslah berujung pada pencapaian learning outcome dan learning performance siswa yang maksimal.

\section{DAFTAR PUSTAKA}

Ambrose, S. A., Bridges, M. W., DiPietro, M., Lovett, M. C., \& Norman, M. K. 
(2010). How Learning Works: Seven Research-Based Principles for Smart Teaching (1st ed.). San Francisco: John Wiley \& Sons, Inc.

Beishuizen, J., \& Steffens, K. (2011). A Conceptual Framework for Research on Self-Regulated Learning. In R. Carneiro, P. Lefrere, K. Steffens, \& J. Underwood (Eds.), Self-Regulated Learning in Technology Enhanced Learning Environments (pp. 3-19). Rotterdam: SensePublishers. https://doi.org/10.1007/978-94-6091654-0_1

Bergey, B. W., Parrila, R. K., \& Deacon, S. H. (2018). Understanding the academic motivations of students with a history of reading difficulty: An expectancyvalue-cost approach. Learning and Individual Differences, 67, 41-52. https://doi.org/10.1016/j.lindif.2018.06. 008

Bhuasiri, W., Xaymoungkhoun, O., Zo, H., Rho, J. J., \& Ciganek, A. P. (2012). Critical success factors for e-learning in developing countries: A comparative analysis between ICT experts and faculty. Computers \& Education, 58(2), 843-855. https://doi.org/10.1016/j.compedu.201 1.10 .010

Broadbent, J., \& Poon, W. L. (2015). Selfregulated learning strategies \& academic achievement in online higher education learning environments: A systematic review. The Internet and Higher Education, 27, 1-13. https://doi.org/10.1016/j.iheduc.2015.0 4.007

Cheng, G., \& Chau, J. (2013). Exploring the relationship between students' selfregulated learning ability and their ePortfolio achievement. The Internet and Higher Education, 17, 9-15. https://doi.org/10.1016/j.iheduc.2012.0 9.005

Cho, M.-H., Kim, Y., \& Choi, D. (2017). The effect of self-regulated learning on college students' perceptions of community of inquiry and affective outcomes in online learning. The Internet and Higher Education, 34, $10-17$.

https://doi.org/10.1016/j.iheduc.2017.0 4.001

Dietrich, J., Viljaranta, J., Moeller, J., \& Kracke, B. (2017). Situational expectancies and task values: Associations with students' effort. Learning and Instruction, 47, 53-64. https://doi.org/10.1016/j.learninstruc. 2 016.10 .009

Eccles, J. S., \& Wigfield, A. (2002). Motivational Beliefs, Values, and Goals. Annual Review of Psychology, 53(1), 109-132. https://doi.org/10.1146/annurev.psych. 53.100901 .135153

Foster, N. L., Rawson, K. A., \& Dunlosky, J. (2018). Self-regulated learning of principle-based concepts: Do students prefer worked examples, faded examples, or problem solving? Learning and Instruction, 55, 124-138. https://doi.org/10.1016/j.learninstruc. 2 017.10 .002

Hamilton-Ekeke, \& Joy-Telu. (2016). Improving Self-Regulated Learning Style amongst Students. International Journal of Secondary Education, 3(6), 72.

https://doi.org/10.11648/j.ijsedu.s.201 5030601.12

Hsiao, H.-S., Tsai, C.-C., Lin, C.-Y., \& Lin, C.-C. (2012). Implementing a selfregulated WebQuest learning system for Chinese elementary schools. Australasian Journal of Educational Technology, 28(2). https://doi.org/10.14742/ajet.876

Keller, J., \& Suzuki, K. (2004). Learner motivation and E-learning design: A multinationally validated process. Journal of Educational Media, 29(3), 229-239.

https://doi.org/10.1080/135816504200 0283084

Kizil, A. Ş., \& Savran, Z. (2016). SELFREGULATED LEARNING IN THE DIGITAL AGE: AN EFL PERSPECTIVE. Novitas-ROYAL (Research on Youth and Language), 10(2), 147-158.

Maldonado-Mahauad, J., Pérez-Sanagustín, M., Kizilcec, R. F., Morales, N., \& Munoz-Gama, J. (2018). Mining theory-based patterns from Big data: Identifying self-regulated learning strategies in Massive Open Online Courses. Computers in Human Behavior, 80, 179-196. https://doi.org/10.1016/j.chb.2017.11.0 11 
Narciss, S., Proske, A., \& Koerndle, H. (2007). Promoting self-regulated learning in web-based learning environments. Computers in Human Behavior, 23(3), 1126-1144.

https://doi.org/10.1016/j.chb.2006.10.0 06

Pintrich, P. R. (1999). The role of motivation in promoting and sustaining selfregulated learning. International Journal of Educational Research, 31(6), 459-470. https://doi.org/10.1016/S08830355(99)00015-4

Pintrich, P. R. (2000). The Role of Goal Orientation in Self-Regulated Learning. In Handbook of Self-Regulation (pp. 451-502).

Elsevier. https://doi.org/10.1016/B978012109890-2/50043-3

Pintrich, P. R. (2004). A Conceptual Framework for Assessing Motivation and Self-Regulated Learning in College Students. Educational Psychology Review, 16(4), 385-407. https://doi.org/10.1007/s10648-0040006-x

Santrock, J. W. (2018). Educational psychology (Sixth Edition). New York: McGraw-Hill Education.

Schunk, D. H. (2012). Learning theories: an educational perspective (6th ed). Boston: Pearson.

Slavin, R. E. (2018). Educational Psychology: theory and practice (Twelfth edition). NY, NY: Pearson.

Wigfield, A., \& Cambria, J. (2010). Students' achievement values, goal orientations, and interest: Definitions, development, and relations to achievement outcomes. Developmental Review, 30(1), 1-35. https://doi.org/10.1016/j.dr.2009.12.00 1

Wigfield, A., \& Eccles, J. S. (2000). Expectancy-Value Theory of Achievement Motivation. Contemporary Educational Psychology, 25(1), 68-81. https://doi.org/10.1006/ceps.1999.101 5

Winters, F. I., Greene, J. A., \& Costich, C. M. (2008). Self-Regulation of Learning within Computer-based Learning Environments: A Critical Analysis. Educational Psychology Review, 20(4), 429-444. https://doi.org/10.1007/s10648-0089080-9

Xu, J. (2017). Homework Expectancy Value Scale for high school students: Measurement invariance and latent mean differences across gender and grade level. Learning and Individual Differences, 60, 10-17. https://doi.org/10.1016/j.lindif.2017.10. 003

Zimmerman, B. J. (2008). Investigating SelfRegulation and Motivation: Historical Background, Methodological Developments, and Future Prospects. American Educational Research Journal, 45(1), 166-183. https://doi.org/10.3102/000283120731 2909

Zimmerman, B. J. (2015). Self-Regulated Learning: Theories, Measures, and Outcomes. In International Encyclopedia of the Social \& Behavioral Sciences (pp. 541-546). Elsevier. https://doi.org/10.1016/B978-0-08097086-8.26060-1

Zumbrunn, S., Tadlock, J., \& Roberts, E. D. (2011). Encouraging Self-Regulated Learning in the Classroom: A Review of the Literature. Metropolitan Educational Research Consortium (MERC), Virginia Commonwealth University. Retrieved from http://www.selfregulation.ca/uploads/5/6/2/6/5626491 5/encouraging_self_regulated_learning in_the_classroom.pdf. 